\title{
The effect of coronaviruses on olfaction: systematic review*
}

\author{
M. Zugaj', N.S. van Ditzhuijzen', K. Golebski², W.J. Fokkens'
}

'Department of Otorhinolaryngology, Amsterdam University Medical Centres, location AMC, Amsterdam, The Netherlands

2 Department of Respiratory Medicine, Amsterdam University Medical Centres, Location AMC, Amsterdam, The Netherlands

Rhinology 59: 0, 0 - 0, 2021

https://doi.org/10.4193/Rhin20.610

*Received for publication:

December 3, 2020

Accepted: January 26, 2021

\begin{abstract}
Background: Unlike other respiratory viruses, SARS-CoV-2 causes anosmia without sinonasal inflammation. Here we systematically review the effects of the 7 known human coronaviruses on olfaction to determine if SARS-CoV-2 distinctly affects the olfactory system.
\end{abstract}

Method: PubMed, EMBASE, Web of Science, bioRxiv, medRxiv and DOAJ were searched for studies describing pathophysiological, immunohistochemical, cytological and clinical data.

Results: 49 studies were included. Common cold coronaviruses lead to sinonasal inflammation which can cause transient and chronic loss of smell. MERS-CoV entry receptors were not found in the nasal mucosa and it did not impair olfaction. SARS-CoV-1 had low affinity for its receptor ACE2, limiting olfactory effects. Anosmia is frequent in SARS-CoV-2 infections. SARS-CoV-2's entry factors ACE2 and TMPRSS2 are expressed in the nasal respiratory epithelium and olfactory supporting cells. SARS-CoV-2 appeared to target the olfactory cleft while diffuse nasal inflammation was not observed. Damage of the olfactory epithelium was observed in animal models. Alternative receptors such as furin and neuropilin-1 and the similarity of viral proteins to odourant receptors could amplify olfactory impairment in SARS-CoV-2 infection.

Conclusions: The pathophysiology of anosmia in SARS-CoV-2 infection is distinct from other coronaviruses due to preferentially targeting olfactory supporting cells. However, SARS-CoV-2 does not cause sinonasal inflammation in spite of preferred entry factor expression in the nasal respiratory epithelium. This raises doubts about the attention given to ACE2. Alternative receptors, odourant receptor mimicry and other as yet unknown mechanisms may be crucial in the pathogenesis of anosmia in SARS-CoV-2 infection. Further studies are warranted to investigate infection mechanisms beyond ACE2.

Key words: Coronaviruses, COVID-19, pathophysiology, olfaction disorders, systematic review

\section{Introduction}

Anosmia is a presenting symptom of coronavirus disease 2019 $\left(\right.$ COVID-19) ${ }^{(1)}$. COVID-19 is caused by the severe acute respiratory syndrome coronavirus 2 (SARS-CoV-2) and can range from asymptomatic to lethal respiratory disease ${ }^{(2)}$. Olfactory dysfunction is reported by $43 \%$ of COVID-19 cases $^{(1)}$. There is wide geographic variation, with a prevalence of $18 \%$ in Asia and $58 \%$ in Europe ${ }^{(1)}$. A recent meta-analysis revealed that anosmia might be underreported, as studies using smell testing report a prevalence of $77 \%$, compared to $45 \%$ when anosmia was self-reported ${ }^{(3)}$. Anosmia occurs as the only complaint in $17 \%$ to
$20 \%$ of cases and is predominant in mild disease ${ }^{(4-6)}$. Olfaction usually returns in 10 to 20 days but $6 \%$ of patients in a recent study reported persistent loss at least 60 days after onset ${ }^{(7)}$. Parosmia is reported by $32 \%$ of patients ${ }^{(6)}$.

Anosmia in SARS-CoV-2 does not seem associated with nasal obstruction and rhinorrhoea ${ }^{(8)}$. This is different from other respiratory viruses, which can cause transient loss of smell by inflammation of the nasal respiratory epithelium, lining most of the nasal cavity ${ }^{(9,10)}$. The olfactory cleft, a small region at the top of the nasal cavity, is lined with olfactory epithelium ${ }^{(10)}$. The olfactory epithelium contains olfactory sensory neurons 
Table 1. Characteristics of human coronaviruses ${ }^{(21,24,36,68,91,92)}$.

\begin{tabular}{|c|c|c|c|c|}
\hline Genus & Species & Disease & Entry receptor & Protease \\
\hline \multirow{2}{*}{ Alpha } & HCoV-NL63 & Common cold & ACE2 & - \\
\hline & HCoV-229E & Common cold & ANPEP & TMPRSS2, CTSL ${ }^{a}$ \\
\hline \multirow{5}{*}{ Beta } & $\mathrm{HCoV}-\mathrm{OC} 43$ & Common cold & Sialic acid & - \\
\hline & HCoV-HKU1 & Common cold & Sialic acid & - \\
\hline & MERS-CoV & MERS & DPP4, Sialic acida , GRP78a & TMPRSS2, CTSL a , Furin ${ }^{a}$ \\
\hline & SARS-COV-1 & SARS & ACE2, DC-SIGN ${ }^{a}$ & $\begin{array}{l}\text { TMPRSS2, CTSL, CTSB } \\
\text { ADAM17, TMPRSS11D }\end{array}$ \\
\hline & SARS-COV-2 & COVID-19 & $\begin{array}{l}\text { ACE2, DC-SIGN, L-SIGN, } \\
\text { Basigina }{ }^{a} \text { Neuropilin-1 }{ }^{a}\end{array}$ & $\begin{array}{l}\text { TMPRSS2, CTSL }{ }^{\text {, }} \text { CTSB } \\
\text { Furin }^{\text {a }}\end{array}$ \\
\hline
\end{tabular}

a Possible alternative entry factor. ACE2, Angiotensin-converting enzyme 2; ADAM17: ADAM metallopeptidase domain 17; TMPRSS, Transmembrane protease, serine; ANPEP, Alanine aminopeptidase; CTSL, Cathepsin L1; CTSB, Cathepsin B; COVID-19, Coronavirus disease 2019; DC-SIGN, Dendritic Cell-Specific Intercellular adhesion molecule-3-Grabbing Non-integrin; GRP78, 78-kDa glucose-regulated protein; HCoV, Human coronavirus; L-SIGN, Liver/lymph node-specific intercellular adhesion molecule-3-grabbing integrin; MERS-CoV: Middle East respiratory syndrome-related coronavirus; SARS-CoV: Severe acute respiratory syndrome coronavirus.

(OSNs) and supporting cells, which include Bowman's glands and sustentacular, microvillar and basal cells ${ }^{(11)}$. Supporting cells are critical to olfaction, and stabilize and repair the olfactory epithelium (11).

When odourants reach the olfactory epithelium, they dissolve in mucous secreted by Bowman's glands (11). The dissolved odourants bind to proteins made by sustentacular cells. This odourant-protein complex binds onto odourant receptors expressed on OSNs, which transduces signals to the brain via the olfactory bulb ${ }^{(10,11)}$. Basal cells ensure the continuous turnover of OSNs ${ }^{(11)}$. Loss of smell in the common cold has been described to be mediated by proinflammatory mediators such as tumour necrosis factor (TNF), interleukins (ILs) and interferons (IFNs) ${ }^{(12)}$. Inflammation in the nasal cavity presents as obstruction and rhinorrhoea, which can block airflow and odourants from reaching the olfactory epithelium ${ }^{(13)}$. Temporary conductive loss is rarely distressing, often goes unnoticed and usually recovers with viral clearance ${ }^{(13)}$.

Transient viral loss of smell can become chronic postviral olfactory dysfunction (PVOD) ${ }^{(9)}$. The pathophysiology is unclear but scarring of the olfactory epithelium was observed in patients with PVOD ${ }^{(14,9)}$. Recovery tends to be slow and uncertain ${ }^{(15)}$. However, studies with long observation periods have shown that olfaction can improve long after the diagnosis. One study found improvement in a third of 246 patients followed for 2 years, while another found 19 of 21 patients improved olfaction after 3 years, with the likelihood and extent of recovery related to the severity of the initial olfactory loss ${ }^{(9,15)}$. Parosmia is reported by $56 \%$ to $65 \%$ of patients during PVOD, thought to arise from incomplete perception due to missing OSNs and the mismatched regeneration of nervous pathways ${ }^{(15-17)}$. Causative viruses are difficult to establish but rhinoviruses, parainfluenza viruses, Epstein-Barr viruses and coronaviruses were identified in patients with PVOD ${ }^{(18,19) \text {. }}$

The seven coronaviruses known to infect humans are Human coronavirus (HCoV)-NL63, HCoV-229E, HCoV-HKU1, HCoV-OC43, Middle East respiratory syndrome coronavirus (MERS-CoV), SARS-CoV-1 and SARS-CoV-2 (Table 1) ${ }^{(20,21)}$. HCoVs are endemic and cause $10 \%$ to $30 \%$ of common colds ${ }^{(21)}$. SARS-CoV- 1 and MERS-CoV cause SARS and MERS, respectively ${ }^{(21)}$. SARS-CoV-1 has not resurfaced since an early 2000 s outbreak ${ }^{(21)}$. MERS-CoV circulates in the Middle East but is fortunately poorly transmitted ${ }^{(22)}$.

Coronaviruses infect targets by attaching viral spike proteins to host cell receptors ${ }^{(23)}$. The spike protein is then cleaved by a host protease, exposing fusion peptides that enable infection (23). Target cells need to co-express a coronavirus' preferred entry factors for successful infection ${ }^{(23)}$. Therefore, the distribution of entry factors governs tissue tropism and pathogenicity ${ }^{(24)}$. Table 1 lists the entry factors used by coronaviruses.

Olfactory and sinonasal symptoms were rarely reported in MERSCoV and SARS-CoV-1 infections, suggesting restricted tropism for the nasal cavity ${ }^{(25)}$. In contrast, $\mathrm{HCoVs}$ are thought to often conductively impair olfaction in the common cold, indicating tropism for the nasal respiratory epithelium ${ }^{(25,26)}$. The unusual presentation of anosmia in SARS-CoV-2 infections suggests that the olfactory mucosa is preferentially targeted. In this systematic review we compare the effects of coronaviruses on olfaction to determine if SARS-CoV-2 distinctly affects the olfactory system.

\section{Methods}

Search

PubMed, EMBASE, Web of Science, bioRxiv, medRxiv and Directory of Open Access Journals (DOAJ) were searched on 


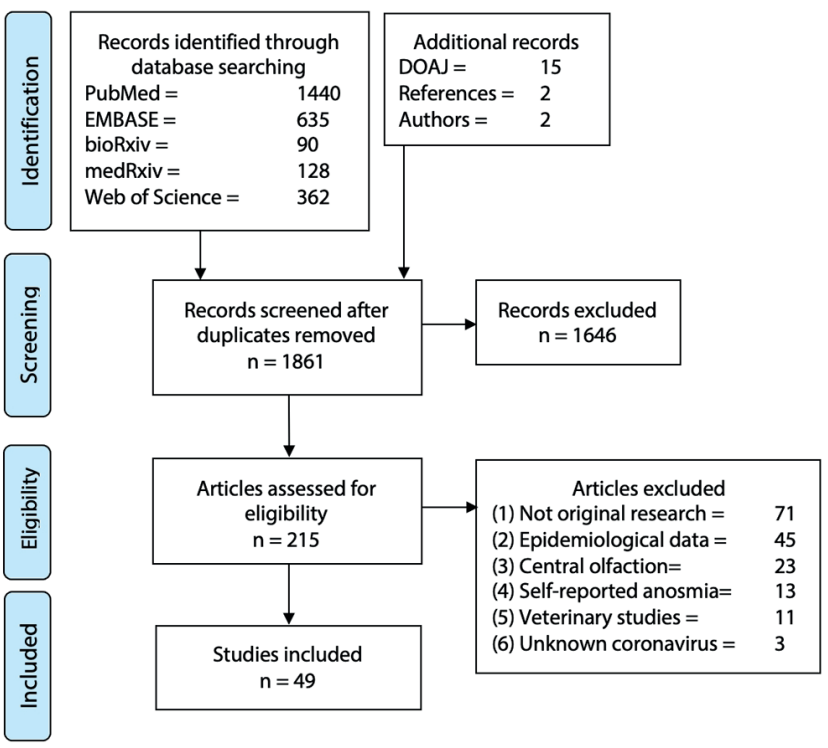

Figure 1. PRISMA selection workflow.

October 7, 2020. Synonyms were organized in three groups: virus, anosmia and pathophysiology. Full queries are shown in Supplement Table 1. References and authors were consulted for adjunct inclusions.

\section{Study selection}

Original studies on olfactory pathology in coronavirus infections with pathophysiological, immunohistochemical, cytological or clinical data were included.

The following studies were excluded: 1) not original research such as reviews and hypotheses, 2) epidemiological studies 3) studies restricted to the olfactory bulb, nerve and brain, 4) case reports on self-reported anosmia without clinical examination,

5) veterinary studies not intended to model human disease and 6) unspecified coronaviruses.

\section{Data extraction}

Key pathophysiological, immunohistochemical, cytological and clinical outcomes were extracted into Supplementary Table 2.

Data extracted on the expression of Angiotensin-converting enzyme 2 (ACE2) and transmembrane protease serine 2 (TMPRSS2) in the olfactory epithelium was extracted into Table 2. Data from imaging studies were extracted into Table 3.

\section{Results}

\section{Study selection}

1861 records were screened. 215 articles were assessed. In total, 48 studies were included (Figure 1). Characteristics of included studies are shown in Supplement Table 2.

\section{HCoVs}

HCoVs infections present as a common cold with nasal obstruc- tion and rhinorrhoea. HCoV-229E was shown to conductively impair olfaction in one study ${ }^{(27)} .78 \%$ of 20 participants infected with HCoV-229E developed hyposmia for at least 4 days after infection ${ }^{(27)}$. The degree of nasal obstruction, determined using nasal peak airflow and acoustic rhinometry, was found to correlate with the severity of olfactory impairment (27). Viruses in patients with PVOD were investigated in two studies ${ }^{(18,19)}$. Both only included patients diagnosed with PVOD following an upper respiratory infection and without olfactory cleft obstruction. Of 24 patients with detectable viruses, HCoV-229E and $\mathrm{HCOV}-\mathrm{OC} 43$ were identified in one patient each ${ }^{(18,19)}$. The HCoV-229E positive patient reported complete anosmia, nasal obstruction and rhinorrhoea on the first visit ${ }^{(18)}$. The patient did not report nasal obstruction and rhinorrhoea on later visits, although olfaction remained impaired. Improvement was reported by week 11 and olfaction fully recovered by week $24^{(18)}$. The findings suggest that inflammation of the nasal respiratory epithelium by HCoV-229E can occasionally damage the olfactory epithelium and lead to sensorineural dysfunction ${ }^{(18,19)}$.

\section{MERS-CoV}

Olfactory pathology was not described as a feature of MERS. The MERS-CoV entry receptor dipeptidyl peptidase-4 (DPP4) was not detected in the nasal tissue ${ }^{(28,29)}$. To investigate if the lack of DPP4 or other entry receptors inhibit MERS-CoV, in one study 6 nasal tissue samples were challenged with MERS-CoV's spike protein ${ }^{(29)}$. Infection was not observed in challenged respiratory or olfactory tissue, suggesting that MERS-CoV lacks nasal tropism and capacity for olfactory pathology ${ }^{(29)}$.

\section{SARS-CoV-1}

Olfactory pathology was not an oft-described feature of SARS. One case report described anosmia in a patient 3 weeks after recovering from SARS-CoV-1 infection with chief complaints of fever, cough, headache and diarrhoea ${ }^{\left({ }^{(0)}\right)}$. Lack of conductive abnormalities on rhinological examination and MRI suggested a diagnosis of sensorineural PVOD, which persisted for at least 2 years after onset ${ }^{(30)}$. However, the patient did not report symptoms of the common cold, which usually precede PVOD (30,9).

The replication of SARS-CoV-1 in the nasal turbinates was modelled in one study using immunosuppressed hamsters ${ }^{(31)}$. Inflammation was not significant, although mild long-lasting damage of the olfactory epithelium was observed ${ }^{(31)}$. Similar damage is seen in PVOD, suggesting SARS-CoV-1 has some, but restricted, tropism for the olfactory epithelium ${ }^{(14)}$.

SARS-CoV-1's interaction with ACE2 was investigated in two studies ${ }^{(32,33)}$. SARS-CoV-1 was found to weakly bind ACE2 at neutral $\mathrm{pH}$ in the nasal cavity ${ }^{(32,33)}$. Weak receptor bonds were hypothesized to be vulnerable to nasal airflow, leading to loose SARS-CoV-1 virions being exhaled or drifting towards the lower 
Table 2. Co-expression of SARS-CoV-2 entry proteins in the olfactory epithelium.

\begin{tabular}{|c|c|c|c|c|c|c|c|c|c|}
\hline Cell & Factor & Ueha ${ }^{(40)}$ & Brann ${ }^{(36)}$ & Gupta $^{(38)}$ & Ziegler ${ }^{(41)}$ & Bilinska $^{(35)}$ & Fodoulian ${ }^{(37)}$ & Muus $^{(39)}$ & Chen ${ }^{(42)}$ \\
\hline \multirow{2}{*}{ OSN } & ACE2 & + & - & - & - & - & - & NA & - \\
\hline & TMPRSS2 & - & - & - & - & + & NA & NA & NA \\
\hline \multirow{2}{*}{ SUS } & ACE2 & + & + & + & $+^{v}$ & + & + & $+^{v}$ & + \\
\hline & TMPRSS2 & + & + & + & $+^{v}$ & + & + & $+^{v}$ & NA \\
\hline \multirow{2}{*}{ BG } & ACE2 & + & + & + & $+^{v}$ & NA & + & + & + \\
\hline & TMPRSS2 & + & + & + & $+v$ & + & + & $t$ & NA \\
\hline \multirow{2}{*}{ MVC } & ACE2 & + & + & - & $+^{v}$ & + & + & & NA \\
\hline & TMPRSS2 & + & + & - & $+^{v}$ & + & + & & NA \\
\hline \multirow{2}{*}{$\mathrm{BC}$} & ACE2 & + & + & + & + & NA & + & & NA \\
\hline & TMPRSS2 & + & + & + & + & + & + & + & NA \\
\hline
\end{tabular}

$\checkmark$, verified with corresponding authors because non-standard terminology was used to describe cell types in original study. OSN, Olfactory sensory neuron; SUS, Sustentacular cell; BG, Bowman's gland; MVC, Microvillar cell; BC, Basal cell; ACE2, Angiotensin-converting enzyme 2; TMPRSS2, Transmembrane protease, serine 2; NA, Not applicable.

respiratory tract ${ }^{(32,33)}$. Therefore, SARS-CoV-1 might have limited time to recruit ACE2 before it is dislodged, limiting the capacity for olfactory pathology ${ }^{(32,33)}$.

\section{SARS-CoV-2}

Nine studies used RNA sequencing or immunohistochemistry to find SARS-CoV-2's entry factors ACE2 and TMPRSS2 in olfactory supporting cells, but not in OSNs (Table 2) ${ }^{(34-42)}$. Sustentacular cells were described to particularly highly co-express ACE2 and TMPRSS2 ${ }^{(35,37)}$. Infection of supporting cells could impair olfaction without diffuse inflammation, consistent with reports of isolated anosmia in COVID-19 ${ }^{(5)}$.

Co-expression of ACE2 and TMPRSS2 was observed in the nasal respiratory epithelium, but the low prevalence of nasal obstruction and rhinorrhoea in COVID-19 suggest that SARS-CoV-2's tropism for nasal respiratory tissue is restricted ${ }^{(36,37,39-41,8)}$. In one study, ACE2 was detected in all 13 included olfactory epithelium samples, while ACE2 was only detected in 9 of 19 included nasal respiratory samples ${ }^{(42)}$. Signal intensities of ACE2 and TMPRSS2 were also higher in the olfactory compared to the respiratory epithelium, suggesting that SARS-CoV-2 can more readily infect tissue lining the olfactory cleft ${ }^{(35,42)}$.

To investigate if SARS-CoV-2 visibly affects the olfactory epithelium, three studies in hamsters were performed ${ }^{(43-45)}$. They demonstrated extensive damage of sustentacular cells quickly after infection, consistent with their co-expression of ACE2 and TMPRSS2 ${ }^{(43-45)}$. OSNs were deciliated, reduced in number and infected ${ }^{(43-45)}$. Olfactory tissue regenerated by day 14 , similar to recovery times in COVID-19 patients with anosmia ${ }^{(44,45)}$. Basal cells were functional but SARS-CoV-2 antigen was detected in the basal layer ${ }^{(45)}$. This suggests that basal cells were compromised but a sufficient immune response cleared the infection. Basal cell disruption is hypothesized to underlie the longer lasting olfactory dysfunction sometimes reported after SARSCoV-2 infection ${ }^{(37,36,45)}$.

Several studies investigated these proposed mechanisms in patients infected with SARS-CoV-2. Diffuse inflammation in the nasal cavity was not detected in 12 imaging studies using CT or MRI, confirming that conductive etiologies do not underlie anosmia in COVID-19 (Table 3$)^{(46-57)}$. However, the olfactory cleft was opacified in 57 of 191 (29.23\%) patients suggesting that SARS-CoV-2's tropism for the olfactory epithelium can lead to

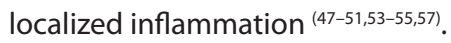

No extensive cell injury was seen using nasal cytology sampled from COVID-19 patients with anosmia, but positive CD68 staining suggested macrophage presence ${ }^{(58,59,48)}$. Limited infiltration of helper and cytotoxic T cells was seen in two olfactory tissue biopsies, although signs of mucosal atrophy and axonal neuritis were described ${ }^{(60-62)}$. Despite limited inflammatory infiltration, patients with mild SARS-CoV-2 infection with olfactory impairment were associated with higher viral burden and longer time to viral clearance compared to patients with normal olfaction ${ }^{(63)}$. These data suggest that SARS-CoV-2 does not provoke a strong immune response in the nasal cavity.

Proinflammatory cytokines might indirectly affect olfaction ${ }^{(64,65)}$. Elevated levels of TNF- $\alpha$ and IL- 6 were detected in COVID-19 patients with anosmia ${ }^{(65,66)}$. TNF- $a$ and IL- 6 were hypothesized to inhibit olfaction with coagulation cascades which can thicken the olfactory mucosa, activate neuroapoptotic pathways and inhibit basal cells ${ }^{(65,66)}$. IFN type 1 and 2 upregulated the 
Table 3. Olfactory cleft opacification in SARS-CoV-2 infected patients.

\begin{tabular}{|c|c|c|c|}
\hline Study & $\begin{array}{l}\text { Imaging mo- } \\
\text { dality }\end{array}$ & $\begin{array}{l}\text { Number of } \\
\text { patients }\end{array}$ & $\begin{array}{l}\text { Patients with } \\
\text { olfactory cleft } \\
\text { opacified }\end{array}$ \\
\hline Brelie $^{(46)}$ & MRI & 1 & 0 \\
\hline Galougahi $^{(56)}$ & MRI & 1 & 0 \\
\hline Laurendon ${ }^{(50)}$ & MRI & 1 & 1 \\
\hline Eliezer ${ }^{(57)}$ & CT & 1 & 1 \\
\hline Chung $^{(48)}$ & СT & 6 & $3(50 \%)$ \\
\hline Tsivgoulis ${ }^{(54)}$ & MRI & 8 & $3(37 \%)$ \\
\hline Girardeu$^{(49)}$ & MRI & 10 & $2(20 \%)$ \\
\hline Lechien $^{(51)}$ & CT & 16 & $3(19 \%)$ \\
\hline Chetrit $^{(47)}$ & MRI & 19 & $9(47 \%)$ \\
\hline Eliezer ${ }^{(55)}$ & MRI & 20 & $19(95 \%)$ \\
\hline Naeini ${ }^{(52)}$ & CT & 49 & 0 \\
\hline Spoldi(53) & СT & 63 & $16(25 \%)$ \\
\hline Total & & 191 & $57(29.23 \%)$ \\
\hline
\end{tabular}

expression of ACE2 and TMPRSS2 in the olfactory epithelium, enhancing the vulnerability of supporting cells ${ }^{(34,36,41)}$. IFN type 1 also directly reduced odourant binding sites by downregulating odourant receptors ${ }^{(67)}$.

Some studies looked further than ACE2. Neuropilin-1, furin and TMPRSS11D were shown to amplify SARS-CoV-2's olfactory tropism ${ }^{(68,69)}$. Furin is not required for SARS-CoV-2 infection, as viral replication continued when furin was knocked out ${ }^{(69)}$. However, furin did enhance direct infection and cell to cell transmission if co-expressed with TMPRSS2 and ACE2 ${ }^{(69)}$. SARS-CoV-2 could use the enhanced transmission to reach cells of the basal layer. Furin was enriched in microvillar cells and Bowman's gland, but not in nasal respiratory cells ${ }^{(41,36,40)}$. Neuropilin-1 similarly amplified infection of the olfactory epithelium and was more abundant than ACE2 in olfactory cells facing the nasal cavity ${ }^{(68)}$.

Genotype variations of nasal entry factors might affect ethnic susceptibility for olfactory pathology ${ }^{(70,71)}$. TMPRSS2 expression was higher in European than in Asian populations which could underlie the higher prevalence of anosmia in Europe ${ }^{(71)}$. Moreover, nasal ACE2 was less methylated in Black individuals and women of all ethnicities ${ }^{(70)}$. Hypomethylation can increase ACE2 availability thereby enhancing SARS-CoV-2's nasal tropism and contribute to the higher frequency of anosmia in women ${ }^{(6,70)}$. SARS-CoV-2's proteins were found to resemble odourant receptors ${ }^{(72)}$. Therefore, immunoglobulin A $(\lg A)$ produced against SARS-CoV-2 may attach to odourant receptors on OSNs and block the transduction of olfactory signals, suggesting an autoimmune component in the pathogenesis of anosmia ${ }^{(72)}$. In another study, gene expression of odourant receptors was downregulated, which could be a consequence of blocked or impaired OSNs ${ }^{(73)}$.

\section{Discussion}

Coronaviruses differently impact olfaction. Transient loss of smell occurs in common colds and can be caused by endemic $\mathrm{HCoVs}{ }^{(21)}$. Evidence on olfactory pathology in $\mathrm{HCoV}$ infections was limited by lack of research interest however. In fact, HCoVNL63 and HCoV-HKU1 were only discovered in the surge of interest after the early 2000 s SARS-CoV-1 outbreak ${ }^{(21)}$. Both viruses had been circulating for decades without great consequence (21). Loss of smell in common colds is usually not reported and virus identification in PVOD is made difficult by delays in seeking care, as viruses can only be detected in lavage up to 4 weeks after onset ${ }^{(18,19,9)}$. Olfactory impairment by HCoVs might thus be underreported.

Olfaction is also not a priority in intensive care units. Therefore, detection bias could have masked olfactory pathology in patients infected with SARS-CoV-1 and MERS-CoV, which more frequently had severe outcomes than SARS-CoV- $2^{(74)}$. SARS-CoV-1 and MERS-CoV also progress faster to severe disease relative to SARS-CoV- $2^{(74,75)}$. This could reduce the window for detecting changes in olfaction.

However, the absence of nasal receptors plausibly explains the lack of olfactory effects in patients infected with MERS-CoV (29). Evidence of MERS-CoV's restricted nasal tropism can also be found in the rarity of other sinonasal symptoms and poor infectivity ${ }^{(22,76)}$. MERS-CoV transmission is usually nosocomial or after contact with camels, where high viral loads can reach DPP4 expressing tissue further down the respiratory tract ${ }^{(22)}$. Community transmission of MERS-CoV was never documented ${ }^{(22,29)}$. In contrast, MERS-CoV is endemic in camel herds and the animals develop symptoms resembling the common cold ${ }^{(77)}$. Camels do express DPP4 nasally, highlighting the importance of nasal receptors in viral tropism and olfactory pathology ${ }^{(29,77)}$.

The only case report of anosmia after SARS-CoV-1 infection is remarkable ${ }^{(30)}$. Common cold symptoms were not reported by the patient and anosmia developed suddenly, weeks after recovering from SARS ${ }^{(30)}$. This differs from typical PVOD that begins as conductive dysfunction then gradually becomes sensorineural (9). The authors hypothesized a relationship with motor neuropathies rarely reported in other SARS-CoV-1 infected patients, however, sensory and motor neuropathies are not interchangeable. The aberrant clinical picture, lack of a validated olfactory test and no comparable reports raise doubts about this case's etiology.

On the contrary, SARS-CoV-1's receptor ACE2 is expressed in the nasal cavity but typical sinonasal symptoms like nasal obstruction and rhinorrhoea were rarely reported during the early $2000 \mathrm{~s}$ SARS-CoV-1 outbreak ${ }^{(76)}$. The scarcity of sinonasal symptoms and evidence gathered in this review suggest that SARS-CoV1 's affinity for nasal ACE2 is low. If olfactory pathology reflects transmission efficiency, then it is not surprising that SARS-CoV-1 took 2 years to peak with 8000 cases ${ }^{(78)}$. Research has indeed 
A
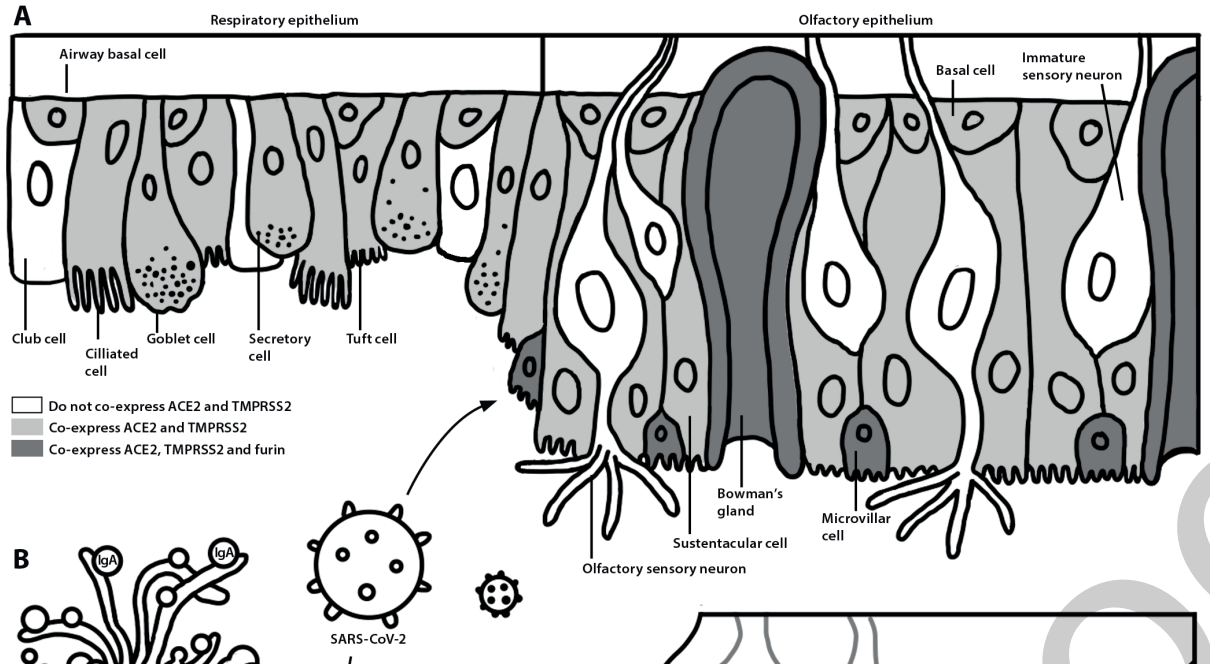

$\int_{\text {Sustentacu }}$

cell

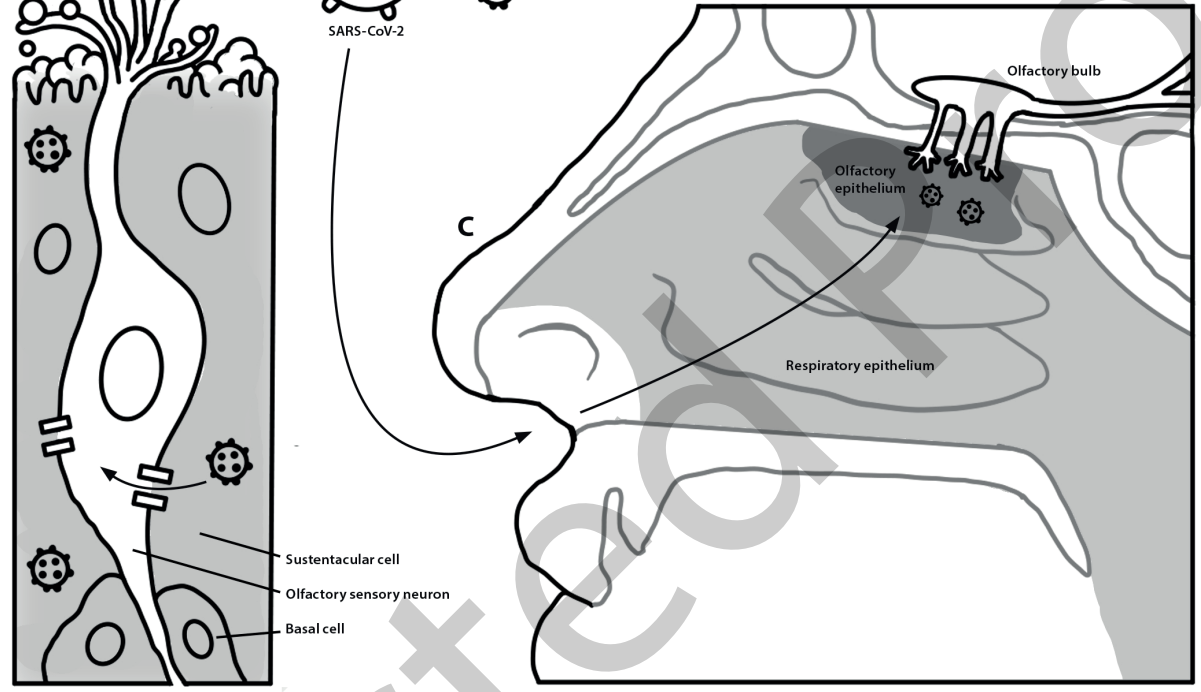

Figure 2. Possible mechanisms of anosmia in SARS-CoV-2 infection (A) Expression of SARS-CoV-2 entry factors in the nasal respiratory and olfactory epithelia. ACE2 and TMPRSS2 co-expressing cells are coloured light grey. Cells additionally expressing furin are coloured dark grey. Respiratory club cells and OSNs were not found to Co-express ACE2 and TMPRSS2. Bowman's glands and microvillar cells' apical location and expression of furin could make them especially vulnerable to SARS-CoV-2 infection. Furin significantly enhances direct infection and cell to cell transmission of SARS-CoV-2 when co-expressed with ACE2 and TMPRSS2. (B) SARS-CoV-2's proteins resemble odourant receptors. IgA made against SARS-CoV-2 can then block odourant receptors. Therefore, anosmia might be a temporary sacrifice for a robust immune response. In addition, sustentacular cells and olfactory are connected with tight junctions, potentially providing an alternative route for olfactory neuroinfection. (C) SARS-CoV-2 appears to preferentially target the olfactory epithelium while bypassing the nasal respiratory epithelium.

indicated that SARS-COV-1's recognition of ACE2 is impaired compared to SARS-CoV-2 ${ }^{(79)}$. This is due to structural differences in the receptor binding domain of SARS-CoV-1's spike protein, which also leads to less robust bonds with ACE2 ${ }^{(79)}$.

Geographic spread could further explain the lack of olfactory impairment by SARS-CoV-1. Anosmia in patients infected with the closely related SARS-CoV-2 is reported more in Europe than in Asia ${ }^{(1)}$. Ethnic variations of entry factors have been proposed to explain this discrepancy ${ }^{(1,8)}$. SARS-CoV-1 was successfully contained in the early 2000s in Asia, suggesting that SARS-CoV-1 was limited to populations resistant to olfactory impairment ${ }^{(78)}$. To understand loss of smell in SARS-CoV-2 infection, scientists used RNA sequencing and immunohistochemistry to define the nasal distribution of ACE2 and TMPRSS2 (Figure 2A). ACE2 and TMPRSS2 were found in the olfactory supporting cells but not in OSNs (Table 2). Sustentacular cells and Bowman's glands provide structural support as they stretch the length from the lamina propria to the apical surface ${ }^{(11)}$. Damage to these structures could disorganize the olfactory epithelium and put cilia of OSNs in positions suboptimal for odourant binding ${ }^{(11)}$. Various critical functions would cease such as electrolyte balance, odourant transport, the mucous layer where odourants dissolve and OSN regeneration ${ }^{(8)}$. However, the rapid recovery of olfaction usually seen in COVID-19 cases indicates that basal cells remain functio- 
nal, as confirmed in one animal model (45).

OSNs seem spared by not co-expressing ACE2 and TMPRSS2, consistent with reports of anosmia as an early but not immediate feature of COVID-19 ${ }^{(80)}$. However, indirection infection of OSNs might still be possible through tight junctions with sustentacular cells (Figure 2B) ${ }^{(11)}$. Infected OSNs were observed in animal models but it is unclear if the same occurs in humans and if SARS-CoV- 2 can propagate further along the olfactory nerve ${ }^{(44,45)}$.

Low prevalence of nasal obstruction and rhinorrhoea suggest the nasal respiratory epithelium is avoided by SARS-CoV-2. Instead, olfactory cleft inflammation occasionally seen with imaging is consistent with the proposed vulnerability of the olfactory epithelium (Figure 2C). This respiratory avoidance is confusing because ACE2 and TMPRSS2 were described across the nasal cavity. In fact, the respiratory lining of the nasal cavity expresses more ACE2 than the lower respiratory tract, the site of severe COVID-19 ${ }^{(81)}$. SARS-COV-2 should encounter ample opportunity for infection before ever reaching the olfactory cleft.

Does SARS-CoV-2 bypass the respiratory epithelium? The olfactory epithelium occupies a small area of the nasal cavity (Figure 2C). This could explain the high signal intensities of ACE2 and TMPRSS2 seen in biopsies of olfactory tissue ${ }^{(35,42)}$. Furthermore, only $8 \%$ of nasal airflow passes along the olfactory cleft, while the rest passes along the respiratory epithelium ${ }^{82)}$. Turbulence in nasal respiratory zones might lead to challenging conditions for SARS-CoV-2, as suggested by studies on the dynamics of ACE2 binding ${ }^{(82,32,33)}$. Although SARS-CoV-2 binds nasal ACE2 more strongly than SARS-CoV-1, nasal airflow could break these bonds. Under those conditions, SARS-CoV-2 could find refuge in the olfactory cleft and replicate undisturbed using ACE2, TMPRSS2, neuropilin-1 and furin.

Besides protective airflow, nasal breathing was suggested to protect against SARS-CoV-2 via nitric oxide produced in the paranasal sinuses ${ }^{\left({ }^{83)}\right.}$. Patients with inefficient nasal respiration might thus be at higher risk of severe disease because the nasal respiratory epithelium leads directly to the lungs. Anosmia could therefore indicate better infection control, a theory consistent with the symptom's predominance in outpatient COVID-19 cases and an association with higher viral loads in mild cases $(84,85,63)$. Indeed, IgA made against SARS-CoV-2 may block OSNs because SARS-CoV-2's proteins resemble odourant receptors (Figure 2B) ${ }^{(72)}$. Downregulation of odourant receptor genes was observed in SARS-CoV-2 clinical specimens, which could be a consequence of IgA occupied odourant receptors ${ }^{(73)}$. Lower mortality and less severe lower respiratory disease were also observed in hospitalized SARS-CoV-2 patients with anosmia

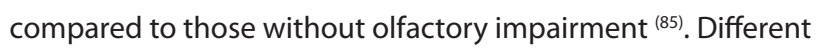
viral loads could underlie the varied clinical presentations but the data is conflicting, as both the upper and lower respiratory tract have been reported as areas of highest viral replication ${ }^{(1,}$
42, 2). Whether patients reporting anosmia better resist an initial viral challenge, or are equally vulnerable to infection but better control SARS-CoV-2, remains an important question. While anosmia is the best predictor of a SARS-CoV-2 diagnosis, it would be interesting to see if nasal obstruction and rhinorrhoea are prognostic for severe disease ${ }^{(86)}$. Importantly, bypass of the nasal respiratory epithelium raises doubts if ACE2 is sufficient to explain anosmia.

Furin and neuropilin-1 might explain this gap ${ }^{(69)}$. Furin enhances direct cell infection and cell to cell transmission when co-expressed with ACE2 and TMPRSS2. Co-expression of Furin, ACE2 and TMPRSS2 was observed in apical supporting cells (Figure 2A). Similar observations were made on neuropilin-1 ${ }^{(68)}$. Interestingly, SARS-CoV-1 was only capable of using furin to enhance cell to cell transmission, additionally restricting SARS-CoV-1's olfactory tropism compared to SARS-CoV-2 ${ }^{(87)}$

An important note regarding this review is that the diverse literature complicates addressing pathophysiology. This is compounded by the inclusion of 14 preprints. Preprints gained relevance with COVID-19 but lack of peer review makes their inclusion risky. Our conclusion on the vulnerability of supporting cells is largely drawn from 24 studies, 5 of which are preprints, with results in line with the peer reviewed literature $34,39,40,43$, 49). However, the dynamics of furin mediated viral entry, $\mathrm{pH}$ dependant ACE2 bond stability, the contribution of nasal airflow, odourant receptor downregulation and ethnic variation of entry receptors were only investigated in preprinted studies $(32,33,40,67$, $69-71,73)$. These findings need to be validated, but their inclusion highlights gaps in research for future study.

An alternative design can be found in Widadgo and Raj's 2016 paper where olfactory tissue was challenged with MERS-CoV's spike protein fused to a mouse antibody ${ }^{(29)}$. Biosafety level 3 labs are required to investigate SARS-CoV-2, but their study design can address olfactory pathophysiology even in smaller laboratories ${ }^{\left({ }^{88}\right)}$. Physiological studies are needed because our conclusions are drawn from evidence using small sample sizes, datasets and animals.

We also excluded neurological studies, although changes in the olfactory bulb were described in several papers ${ }^{(36,49,50,54,56,66)}$. Future studies should explore if this is because of infection in the olfactory bulb or neuroplasticity due to reduced signalling from the olfactory epithelium.

\section{Conclusion}

In this review we highlighted SARS-CoV-2's tropism for olfactory supporting cells. Their vulnerability stems from co-expression of ACE2 and TMPRSS2. However, despite ACE2 and TMPRSS2 co-expression in the nasal respiratory epithelium, sinonasal inflammation is not prevalent in SARS-CoV-2 infection. This raises doubts about the predominant focus on ACE2 in research. Furin and neuropilin-1 could be important in the pathogenesis 
of anosmia in SARS-CoV-2 infection, while mechanisms such as odourant receptor mimicry warrant further attention. Fortunately, anosmia after SARS-CoV-2 appears transient in most cases (89). The complex response to SARS-CoV-2 in the nasal cavity deserves continued research however. For example, prophylactic antagonism of toll-like receptors and neuropilin-1 in the nasal epithelium were shown to inhibit SARS-CoV-2 ${ }^{(68,90)}$. With concerns about new mutations and vaccines' long-term efficacy, the distinct effects of SARS-CoV-2 on olfaction could reveal novel targets for intervention.

\section{Authorship contribution}

MZ: design, search, analysis, manuscript. NvD: design, analysis, revision. KG: expert opinion, revision, WF: design, analysis, expert opinion, revision.

\section{Conflict of interest}

No conflict of interest.

\section{Financial disclosure}

No funding.

\section{References}

1. von Bartheld CS, Hagen MM, Butowt R. Prevalence of Chemosensory Dysfunction in COVID-19 Patients: A Systematic Review and Meta-analysis Reveals Significant Ethnic Differences. ACS Chem Neurosci. 2020; 11(19): 2944-61.

2. Riggioni C, Comberiati P, Giovannini $M$, et al. A compendium answering 150 questions on COVID-19 and SARS-CoV-2. Allergy. 2020; 75(10): 2503-41.

3. Hannum ME, Ramirez VA, Lipson SJ, et al. Objective Sensory Testing Methods Revea a Higher Prevalence of Olfactory Loss in COVID-19-Positive Patients Compared to Subjective Methods: A Systematic Review and Meta-Analysis. Chem Senses. 2020 Dec 5:45(9):865-874.

4. Hopkins C, Surda P, Kumar N. Presentation of new onset anosmia during the COVID-19 pandemic. Rhinology. 2020; 58(3) :295-8.

5. Borsetto D, Hopkins C, Philips V, et al. Self-reported alteration of sense of smell or taste in patients with COVID-19: a systematic review and meta-analysis on 3563 patients. Rhinology. 2020; 58(5): 430-6.

6. Lechien JR, Chiesa-Estomba CM, De Siati DR, et al. Olfactory and gustatory dysfunctions as a clinical presentation of mild-tomoderate forms of the coronavirus disease (COVID-19): a multicenter European study. Eur Arch Otorhinolaryngol. 2020; 277(8): 2251-61.

7. Vaira LA, Hopkins C, Petrocelli M, et al. Smell and taste recovery in coronavirus disease 2019 patients: a 60-day objective and prospective study. J Laryngol Otol. 2020; 134(8): 703-9.

8. Lechien JR, Chiesa-Estomba CM, Place S, et al. Clinical and epidemiological characteris tics of 1420 European patients with mild-tomoderate coronavirus disease 2019. J Intern Med. 2020; 288(3): 335-44.

9. Hummel T, Whitcroft KL, Andrews P, et al. Position paper on olfactory dysfunction. Rhinology. 2016; 56(1): 1-30.

10. Landis BN, Briner HR, Lacroix JS, Simmen D. Olfaction and Its Disorders. In: Georgalas C, Fokkens WJ, eds. Rhinology and skull base surgery: from the lab to the operating room: an evidence-based approach. Stuttgart: Thieme; 2013; 195-199.
11. Chen CR, Kachramanoglou C, Li D Andrews P, Choi D. Anatomy and Cellular Constituents of the Human Olfactory Mucosa: A Review. J Neurol Surg B Skul Base. 2014; 75(5): 293-300.

12. Fokkens WJ, Lund VJ, Hopkins C, et al. European Position Paper on Rhinosinusitis and Nasal Polyps 2020. Rhinology. 2020; 58(Suppl S29): 1-464.

13. Hummel T, Rothbauer C, Barz S, Grosser K, Pauli E, Kobal G. Olfactory function in acute rhinitis. Ann N Y Acad Sci. 1998; 855: 616-24.

14. Jafek BW, Murrow B, Michaels R, Restrepo D, Linschoten M. Biopsies of Human Olfactory Epithelium. Chem Senses. 2002; 27(7): 6238

15. Seiden AM. Postviral olfactory loss Otolaryngologic Clinics of North America. 2004; 37(6): 1159-66.

16. Reden J, Maroldt H, Fritz A, Zahnert T, Hummel T. A study on the prognostic significance of qualitative olfactory dysfunction. Eur Arch Otorhinolaryngol. 2006; 264(2): 139.

17. Rombaux P, Martinage S, Huart C, Collet S. Post-infectious olfactory loss: a cohort study and update. B-ENT. 2009; 5 Suppl 13: 89-95.

8. Suzuki M, Saito K, Min W, et al. Identification of Viruses in Patients With Postviral Olfactory Dysfunction. Laryngoscope. 2007; 117(2): 272-7

19. Tian J, Pinto JM, Li L, Zhang S, Sun Z, Wei Y. Identification of Viruses in Patients With Postviral Olfactory Dysfunction by Multiplex Reverse-Transcription Polymerase Chain Reaction. Laryngoscope. 2021 Jan;131(1):158-164.

20. Gorbalenya AE, Baker SC, Baric RS, et al. The species Severe acute respiratory syndromerelated coronavirus: classifying 2019nCoV and naming it SARS-CoV-2. Nature Microbiology. 2020; 5(4): 536-44.

21. Corman VM, Lienau J, Witzenrath M Coronaviren als Ursache respiratorischer Infektionen. Internist (Berl). 2019; 60(11): 1136-45.

22. Memish ZA, Perlman S, Kerkhove MDV, Zumla A. Middle East respiratory syndrome. Lancet. 2020; 395(10229): 1063-77.

23. Fehr AR, Perlman S. Coronaviruses: An Overview of Their Replication and
Pathogenesis. Coronaviruses. 2015; 1282 : $1-23$.

24. Lim YX, Ng YL, Tam JP, Liu DX. Human Coronaviruses: A Review of Virus-Host Interactions. Diseases. 2016; 4(3): 26

25. Rockx B, Kuiken T, Herfst $S$, et al. Comparative pathogenesis of COVID-19, MERS, and SARS in a nonhuman primate model. Science. 2020; 368(6494): 1012-5.

26. Chan RWY, Chan MCW, Agnihothram $S$, et al. Tropism of and Innate Immune Responses to the Novel Human Betacoronavirus Lineage C Virus in Human Ex Vivo Respiratory Organ Cultures. J Virol. 2013; 87(12): 6604-14.

27. Akerlund A, Bende M, Murphy C. Olfactory threshold and nasal mucosal changes in experimentally induced common cold. Acta Otolaryngol. 1995; 115(1): 88-92.

28. Meyerholz DK, Lambertz AM, McCray PBJ. Dipeptidyl Peptidase 4 Distribution in the Human Respiratory Tract: Implications for the Middle East Respiratory Syndrome. Am J Pathol. 2016; 186(1): 78-86.

29. Widagdo W, Raj VS, Schipper D, et al. Differential Expression of the Middle East Respiratory Syndrome Coronavirus Receptor in the Upper Respiratory Tracts of Humans and Dromedary Camels. J Virol. 2016; 90(9): 4838-42.

30. Hwang C-S. Olfactory neuropathy in severe acute respiratory syndrome: report of $A$ case. Acta Neurol Taiwan. 2006; 15(1): 26-8.

31. Schaecher SR, Stabenow J, Oberle C, et al. An immunosuppressed Syrian golden hamster model for SARS-CoV infection. Virology. 2008; 380(2): 312-21.

32. Paris KA, Santiago U, Camacho CJ. Loss of $\mathrm{pH}$ switch unique to SARS-CoV2 supports unfamiliar virus pathology. bioRxiv. 2020; 2020.06.16.155457. [Preprint]

33. Paris KA, Santiago U, Camacho CJ. On the molecular mechanism of SARS-CoV-2 retention in the upper respiratory tract. bioRxiv. 2020; 2020.07.29.227389. [Preprint]

34. Baxter BD, Larson ED, Feinstein P, et al. Transcriptional profiling reveals TRPM5expressing cells involved in viral infection in the olfactory epithelium. bioRxiv. 2020; 2020.05.14.096016. [Preprint]

35. Bilinska K, Jakubowska P, Von Bartheld CS, Butowt R. Expression of the SARS-CoV-2 
Entry Proteins, ACE2 and TMPRSS2, in Cells of the Olfactory Epithelium: Identification of Cell Types and Trends with Age. ACS Chem Neurosci. 2020; 11(11): 1555-62.

36. Brann DH, Tsukahara T, Weinreb C, et al. Non-neuronal expression of SARS-CoV-2 entry genes in the olfactory system suggests mechanisms underlying COVID19-associated anosmia. Sci Adv. 2020 Jul 31:6(31):eabc5801.

37. Fodoulian L, Tuberosa J, Rossier D, et al. SARS-CoV-2 receptor and entry genes are expressed by sustentacular cells in the human olfactory neuroepithelium. bioRxiv. 2020;2020.03.31.013268. [Preprint]

38. Gupta K, Mohanty SK, Mittal A, et al. The Cellular basis of the loss of smell in 2019-nCoV-infected individuals. Brief Bioinform. 2021 Mar 22;22(2):873-881.

39. Muus C, Luecken MD, Eraslan G, et al Integrated analyses of single-cell atlases reveal age, gender, and smoking status associations with cell type-specific expression of mediators of SARS-CoV-2 viral entry and highlights inflammatory programs in putative target cells. bioRxiv. 2020;2020.04.19.049254. [Preprint]

40. Ueha R, Kondo K, Kagoya R, Shichino S, Ueha S, Yamasoba T. Understanding olfactory dysfunction in COVID-19: Expression of ACE2, TMPRSS2 and Furin in the nose and olfactory bulb in human and mice. Rhinology. 2021 Feb 1;59(1):105-109.

41. Ziegler CGK, Allon SJ, Nyquist SK, et al. SARS-CoV-2 Receptor ACE2 Is an InterferonStimulated Gene in Human Airway Epithelial Cells and Is Detected in Specific Cell Subsets across Tissues. Cell. 2020; 181(5): 1016-1035.e19.

42. Chen M, Shen W, Rowan NR, et al. Elevated ACE-2 expression in the olfactory neuroepithelium: implications for anosmia and upper respiratory SARS-CoV-2 entry and replication. Eur Respir J. 2020; 56(3): 2001948.

43. Bryche B, Albin AS, Murri S, et al. Massive transient damage of the olfactory epithelium associated with infection of sustentacular cells by SARS-CoV-2 in golden Syrian hamsters. bioRxiv. 2020; 2020.06.16.151704. [Preprint]

44. Sia SE, Yan L-M, Chin AWH, et al. Pathogenesis and transmission of SARSCoV-2 in golden hamsters. Nature. 2020; 583(7818): 834-8.

45. Zhang AJ, Lee AC, Chu H, et al. SARS-CoV-2 infects and damages the mature and immature olfactory sensory neurons of hamsters. Clin Infect Dis. 2020 Jul 15. doi:10.1093/cid/ ciaa995 [Epub ahead of print]

46. Brelie LF der, Becker C, Brelie C von der. Parosmia as an Early Symptom of Acute SARS-CoV-2 Infection. Dtsch Arztebl Int 2020; 117(18): 328.

47. Chetrit A, Lechien JR, Ammar A, et al Magnetic resonance imaging of COVID-19 anosmic patients reveals abnormalities of the olfactory bulb: Preliminary prospective study. J Infect. 2020; 81(5): 816-846.

48. Chung TW-H, Sridhar S, Zhang AJ, et al. Olfactory Dysfunction in Coronavirus Disease 2019 Patients: Observational Cohort Study and Systematic Review. Open Forum Infect Dis. 2020; 7(6): ofaa199.

49. Girardeau Y, Gallois Y, Bonnecaze GD, et al. Confirmed central olfactory system lesions on brain MRI in COVID-19 patients with anosmia: a case-series. medRxiv. 2020; 2020.07.08.20148692. [Preprint]

50. Laurendon T, Radulesco T, Mugnier J, et al. Bilateral transient olfactory bulb edema during COVID-19-related anosmia. Neurology. 2020; 95(5): 224-5.

51. Lechien JR, Michel J, Radulesco T, et al. Clinical and Radiological Evaluations of COVID-19 Patients With Anosmia: Preliminary Report Laryngoscope. $2020 \mathrm{Jul}$ 18. doi:10.1002/lary.28993 [Epub ahead of print]

52. Naeini AS, Karimi-Galougahi M, Raad N, et al. Paranasal sinuses computed tomography findings in anosmia of COVID-19. Am . Otolaryngol. 2020; 41(6): 102636.

53. Spoldi C, Castellani L, Pipolo C, et al. Isolated olfactory cleft involvement in SARS-CoV-2 infection: prevalence and clinical correlates. Eur Arch Otorhinolaryngol. 2020 Jun 23. doi:10.1007/s00405-020-06165-7 [Epub ahead of print]

54. Tsivgoulis G, Fragkou PC, Lachanis S, et al. Olfactory bulb and mucosa abnormalities in persistent COVID-19 induced anosmia: A Magnetic Resonance Imaging study. Eur J Neurol. 2020 Sep 16. doi: 10.1111/ ene.14537 [Epub ahead of print]

55. Eliezer M, Hamel A-L, Houdart E, et al. Loss of smell in COVID-19 patients: MRI data reveals a transient edema of the olfactory clefts. Neurology. 2020 Sep 11. doi: 10.1212/ WNL.0000000000010806. [Epub ahead of print]

56. Galougahi MK, Ghorbani J, Bakhshayeshkaram M, Naeini AS, Haseli S. Olfactory Bulb Magnetic Resonance Imaging in SARS-CoV-2-Induced Anosmia: The First Report. Acad Radiol. 2020; 27(6): 892-3.

57. Eliezer M, Hautefort C, Hamel A-L, et al. Sudden and Complete Olfactory Loss of Function as a Possible Symptom of COVID19. JAMA Otolaryngol Head Neck Surg. 2020; 146(7): 674-5

58. Gelardi M, Notargiacomo M, Trecca EMC, Cassano M, Ciprandi G. COVID-19 and Nasal Cytobrush Cytology. Acta Cytol. 2020; 64(4): 397-8.

59. Gelardi M, Notargiacomo M, Trecca EMC, Cassano M. SARS-CoV-2: Naso-bronchial cytological correlations. Am J Otolaryngol. 2020; 41(4): 102549

60. Kirschenbaum D., Imbach L.L., Ulrich S., et al. Inflammatory olfactory neuropathy in two patients with COVID-19. Lancet. 2020; 396(10245): 166.

61. Morbini $P$, Benazzo $M$, Verga $L$, et al. Ultrastructural Evidence of Direct Viral
Damage to the Olfactory Complex in Patients Testing Positive for SARS-CoV-2. JAMA Otolaryngol Head Neck Surg. 2020 Aug 13. doi: 10.1001/jamaoto.2020.2366. [Epub ahead of print]

62. Meinhardt J, Radke J, Dittmayer C, et al. Olfactory transmucosal SARS-CoV-2 invasion as port of Central Nervous System entry in COVID-19 patients. bioRxiv. 2020; 2020.06.04.135012. [Preprint]

63. Nakagawara K, Masaki K, Uwamino Y, et al. Acute onset olfactory/taste disorders are associated with a high viral burden in mild or asymptomatic SARS-CoV-2 infections. Int $J$ Infect Dis. 2020; 99:19-22.

64. Melo CVB de, Bhuiyan MA, Gatua WN, et al. Transcriptomic dysregulations associated with SARS-CoV-2 infection in human nasopharyngeal and peripheral blood mononuclear cells. bioRxiv. 2020; 2020.09.09.289850. [Preprint]

65. Torabi A, Mohammadbagheri E, Akbari Dilmaghani $N$, et al. Proinflammatory Cytokines in the Olfactory Mucosa Result in COVID-19 Induced Anosmia. ACS Chem Neurosci. 2020; 11 (13):1909-13.

66. Cazzolla AP, Lovero R, Lo Muzio L, et al. Taste and Smell Disorders in COVID-19 Patients: Role of Interleukin-6. ACS Chem Neurosci. 2020; 11(17): 2774-81.

67. Rodriguez S, Cao L, Rickenbacher GT, et al. Innate immune signaling in the olfactory epithelium reduces odorant receptor levels: modeling transient smell loss in COVID-19 patients. medRxiv. 2020; 2020.06.14.20131128 [Preprint]

68. Cantuti-Castelvetri L, Ojha R, Pedro LD, et al. Neuropilin-1 facilitates SARS-CoV-2 cell entry and infectivity. Science. 2020; 370(6518):856-60.

69. Papa G, Mallery DL, Albecka A, et al. Furin cleavage of SARS-CoV-2 Spike promotes but is not essential for infection and cell-cell fusion. bioRxiv. 2020; 2020.08.13.243303. [Preprint]

70. Cardenas A, Rifas-Shiman SL, Sordillo JE, et al. DNA Methylation Architecture of the ACE2 gene in Nasal Cells. medRxiv. 2020; 2020.08.25.20182105. [Preprint]

71. Santos NPC, Khayat AS, Rodrigues JCG, et al. TMPRSS2 variants and their susceptibility to COVID-19: focus in East Asian and European populations. medRxiv. 2020; 2020.06.09.20126680. [Preprint]

72. Root-Bernstein R. Anosmia-hyposmia and dysgeusia in COVID-19 may be due to SARS-CoV-2 protein mimicry of olfactory receptors. Rhinology Online. 2020; 3(3): 148-51.

73. Butler DJ, Mozsary C, Meydan C, et al. Shotgun Transcriptome and Isothermal Profiling of SARS-CoV-2 Infection Reveals Unique Host Responses, Viral Diversification, and Drug Interactions. bioRxiv. 2020; 2020.04.20.048066. [Preprint]

74. Zhu Z, Lian X, Su X, Wu W, Marraro GA, Zeng Y. From SARS and MERS to COVID-19: a brief summary and comparison of severe 
acute respiratory infections caused by three highly pathogenic human coronaviruses. Respiratory Research. 2020; 21(1): 224

75. Chu H, Chan JF-W, Yuen TT-T, et al. Comparative tropism, replication kinetics, and cell damage profiling of SARS-CoV-2 and SARS-CoV with implications for clinical manifestations, transmissibility, and laboratory studies of COVID-19: an observational study. The Lancet Microbe. 2020; 1(1): e14-23.

76. Lehrich BM, Goshtasbi K, Raad RA, et al. Aggregate Prevalence of Chemosensory and Sinonasal Dysfunction in SARS-CoV-2 and Related Coronaviruses. Otolaryngol Head Neck Surg. 2020; 163(1): 156-61.

77. Haverkamp A-K, Lehmbecker A, Spitzbarth I, et al. Experimental infection of dromedaries with Middle East respiratory syndromeCoronavirus is accompanied by massive ciliary loss and depletion of the cell surface receptor dipeptidyl peptidase 4 . Sci Rep. 2018; 8(1): 9778

78. WHO | Cumulative Number of Reported Probable Cases of SARS [Internet]. WHO. World Health Organization; [cited 2020 Aug 9]. Available from: https://www.who.int/csr/ sars/country/2003_07_11/en/

79. Shang J, Ye G, Shi K, et al. Structural basis of receptor recognition by SARS-CoV-2. Nature. 2020; 581(7807): 221-4.

80. Whitehead DEJ, Kelly C, Ahmad N. A case series of patients, including a consultant rhinologist, who all experienced a loss of smell associated with confirmed or suspected COVID-19. Rhinology Online. 2020; 3(3): 67-72.
81. Hou YJ, Okuda K, Edwards CE, et al. SARS CoV-2 Reverse Genetics Reveals a Variable Infection Gradient in the Respiratory Tract Cell. 2020; 182(2): 429-446.e14.

82. Zhao K, Scherer PW, Hajiloo SA, Dalton P. Effect of Anatomy on Human Nasal Air Flow and Odorant Transport Patterns: Implications for Olfaction. Chem Senses. 2004; 29(5): 365-79.

83. Martel J, Ko Y-F, Young JD, Ojcius DM. Could nasal nitric oxide help to mitigate the severity of COVID-19? Microbes Infect. 2020; 22(4): 168-71

84. Le Bon SD, Horoi M. Is anosmia the price to pay in an immune-induced scorched-earth policy against COVID-19? Med Hypotheses. 2020; 143: 109881.

85. Talavera B, García-Azorín D, Martínez-Pías E, et al. Anosmia is associated with lower in hospital mortality in COVID-19. J Neurol Sci. 2020; 419: 117163.

86. Reitsma S, Lund VJ, Carrie S, Fokkens WJ. ERS member survey on COVID-19 symptomatology and personal protection: a construct to predict early COVID-19 disease. Rhinology Online. 2020; 3(3): 31-7.

87. Follis KE, York J, Nunberg JH. Furin cleavage of the SARS coronavirus spike glycoprotein enhances cell-cell fusion but does not affect virion entry. Virology. 2006; 350(2): 358-69.

88. Iwen PC, Stiles KL, Pentella MA. Safety Considerations in the Laboratory Testing of Specimens Suspected or Known to Contain the Severe Acute Respiratory Syndrome Coronavirus 2 (SARS-CoV-2). Lab Med. 2020; 51(3): 239-42.
89. Vaira LA, Salzano G, Fois AG, Piombino P, De Riu G. Potential pathogenesis of ageusia and anosmia in COVID-19 patients. Int Forum Allergy Rhinol. 2020; 10(9): 1103-4.

90. Proud PC, Tsitoura D, Watson RJ, et al. Prophylactic intranasal administration of a TLR2 agonist reduces upper respiratory tract viral shedding in a SARS-CoV-2 challenge ferret model. bioRxiv. 2020; 2020.09.25.309914 [Preprint]

91. Descamps G, Verset L, Trelcat A, et al. ACE2 Protein Landscape in the Head and Neck Region: The Conundrum of SARS-COV-2 Infection. Biology (Basel). 2020; 9(8): 235

92. Amraie $R$, Napoleon MA, Yin $W$, et al. CD209L/L-SIGN and CD209/DC-SIGN act as receptors for SARS-COV-2 and are differentially expressed in lung and kidney epithelial and endothelial cells. bioRxiv. 2020; 2020.06.22.165803. [Preprint].

Mislav Žugaj

Amsterdam UMC, locatie AMC

Meibergdreef 9

1105 AZ Amsterdam

the Netherlands

E:m.zugaj@amsterdamumc.nl 


\section{SUPPLEMENTARY DATA}

Supplement Table 1. Search queries.

\begin{tabular}{|c|c|c|c|}
\hline Database & Virus & (AND) Anosmia & (AND) Mechanism \\
\hline $\begin{array}{l}\text { PubMed } \\
\text { EMBASE } \\
\text { Web of Science }\end{array}$ & $\begin{array}{l}\text { (covid-19 OR covid* OR novel corona- } \\
\text { virus OR nCoV OR SARS-CoV-2 OR coro- } \\
\text { navirus OR coronavirus* OR coronavirus } \\
\text { infections OR (severe acute respiratory } \\
\text { syndrome OR SARS-COV OR SARS coro- } \\
\text { navirus OR SARS-related coronavirus) } \\
\text { OR (middle east respiratory syndrome } \\
\text { OR middle east respiratory syndrome } \\
\text { coronavirus OR MERS-CoV OR MERS } \\
\text { OR MERS coronavirus OR MERS-related } \\
\text { coronavirus) OR (betacoronavirus OR } \\
\text { alphacoronavirus OR human coronavi- } \\
\text { rus OR human coronavirus* OR HCOV } \\
\text { OR coronavirus NL63 OR coronavirus } \\
229 E \text { OR coronavirus HKU1 OR corona- } \\
\text { virus OC43)) }\end{array}$ & $\begin{array}{l}\text { (olfact* OR smell OR anosmia OR } \\
\text { hyposmia OR microsmia OR hyperosmia } \\
\text { OR dysosmia OR parosmia OR PVOD OR } \\
\text { ((postviral OR post-viral OR post viral OR } \\
\text { viral OR post-infectious OR post infecti- } \\
\text { ous OR postinfectious) AND (olfactory } \\
\text { OR olfaction OR smell) AND (disorder OR } \\
\text { dysfunction OR impairment)) OR ((smell } \\
\text { OR olfaction OR olfactory OR nasal OR } \\
\text { sino-nasal OR sinonasal OR chemo- } \\
\text { sensory OR sensory) AND (symptoms } \\
\text { OR sequelae OR blindness OR loss OR } \\
\text { impairment OR damage OR dysfunc- } \\
\text { tion OR neuropathy OR pathology OR } \\
\text { pathophysiology))) }\end{array}$ & $\begin{array}{l}\text { (histology OR immunopathology OR } \\
\text { pathology OR pathophysiology OR } \\
\text { physiopathology OR pathogenesis OR } \\
\text { mechanism OR etiology OR aetiology } \\
\text { OR otorhinolaryngology OR otolaryn- } \\
\text { gology OR rhinology OR immunology } \\
\text { OR (nasal epithelium OR olfactory } \\
\text { epithelium OR nasal neuroepithelium } \\
\text { OR respiratory epithelium OR epithelial } \\
\text { cells) OR ((olfaction OR olfactory OR na- } \\
\text { sal) AND (mucosa OR epithelium OR tis- } \\
\text { sue OR system OR nerves OR anatomy)) } \\
\text { OR olfactory perception OR (olfactory } \\
\text { receptor OR olfactory receptor neurons } \\
\text { OR OSN OR ORN) OR olfactory bulb OR } \\
\text { olfactory cleft OR olfactory pathway OR } \\
\text { nasal cavity) }\end{array}$ \\
\hline DOAJ & $\begin{array}{l}\text { (SARS-CoV-2 OR COVID-19 OR corona- } \\
\text { virus*) }\end{array}$ & (anosmia OR olfactory+dysfun & INA \\
\hline $\begin{array}{l}\text { bioRxiv } \\
\text { MedRxiv }\end{array}$ & covid-19+sars-cov-2+corona* & $\begin{array}{l}\text { smell+nasal+anosmia+ "olfactory d } \\
\text { function"+ hyposmia+parosmia+olf }\end{array}$ & NA \\
\hline
\end{tabular}

NA, not applicable.

Supplement Table 2. Characteristics and key outcomes of included studies.

\begin{tabular}{|c|c|c|c|c|c|}
\hline Journal & Year & First author & Virus & Design & Outcomes \\
\hline Laryngoscope & 2007 & Suzuki ${ }^{(18)}$ & HCoVs & Prospective & HCoV-229E in one PVOD patient \\
\hline Laryngoscope & 2020 & $\operatorname{Tian}^{(19)}$ & HCoVs & Prospective & HCoV-OC43 in one PVOD patient \\
\hline Acta Otolaryngol & 1995 & Akerlund $^{(27)}$ & HCoVs & Observational & $\begin{array}{l}\text { hyposmia correlated with nasal obstruction after } \\
\text { HCoV-229E }\end{array}$ \\
\hline J Virol & 2016 & Widagdo ${ }^{(29)}$ & MERS-CoV & immunhistochemistry & $\begin{array}{l}\text { MERS-CoV did not infect challenged respiratory } \\
\text { and olfactory tissue, suggesting no DPP4 or } \\
\text { alternative entry receptors }\end{array}$ \\
\hline Am J Pathol & 2016 & Meyerholz ${ }^{(28)}$ & MERS-CoV & immunhistochemistry & no DPP4 in nasal mucosa \\
\hline Acta Neurol Taiwan & 2006 & Hwang $^{(30)}$ & SARS-CoV-1 & Case report & $\begin{array}{l}\text { Case report of anosmia after SARS-CoV- } 1 \text { infec- } \\
\text { tion with no preceding sinonasal inflammation }\end{array}$ \\
\hline Virology & 2008 & Schaecher ${ }^{(31)}$ & SARS-CoV-1 & Animal model & mild long-lasting olfactory epithelium damage \\
\hline preprint & 2020 & Paris ${ }^{(32)}$ & $\begin{array}{l}\text { SARS-CoV-1, } \\
\text { SARS-CoV-2 }\end{array}$ & Simulation & $\begin{array}{l}\text { SARS-CoV-2 lacks pH switch, leading to tighter } \\
\text { ACE2 bods } \\
\text { SARS-CoV-1 has a pH switch leading to looser } \\
\text { ACE2 bonds }\end{array}$ \\
\hline preprint & 2020 & Paris $^{(33)}$ & $\begin{array}{l}\text { SARS-CoV-1, } \\
\text { SARS-CoV-2 }\end{array}$ & Simulation & $\begin{array}{l}\text { SARS-CoV-2 lacks pH switch, leading to tighter } \\
\text { ACE2 bonds } \\
\text { SARS-CoV-1 has a pH switch leading to looser } \\
\text { ACE2 bonds }\end{array}$ \\
\hline $\begin{array}{l}\text { JAMA Otolaryngol } \\
\text { Head Neck Surg }\end{array}$ & 2020 & Eliezer $^{(57)}$ & SARS-CoV-2 & Case report, CT & Olfactory cleft opacification 1/1 \\
\hline Open Forum Infect Dis & 2020 & Chung $^{(48)}$ & SARS-CoV-2 & Case cohort, CT & Olfactory cleft opacification $3 / 6$ \\
\hline Am J Otolaryngol & 2020 & Naeini ${ }^{(52)}$ & SARS-CoV-2 & Case cohort, CT & Olfactory cleft opacification 0/49 \\
\hline preprint & 2020 & Baxter ${ }^{(34)}$ & SARS-CoV-2 & RNAseq & $\begin{array}{l}\text { IFN type I and II induced by response to SARS- } \\
\text { CoV-2 upregulates nasal ACE2 expression }\end{array}$ \\
\hline
\end{tabular}




\begin{tabular}{|c|c|c|c|c|c|}
\hline Journal & Year & First author & Virus & Design & Outcomes \\
\hline ACS Chem Neurosci & 2020 & Bilinska $^{(35)}$ & SARS-CoV-2 & $\begin{array}{l}\text { Immunohistoche- } \\
\text { mistry }\end{array}$ & $\begin{array}{l}\text { ACE2 and TMPRSS } 2 \text { co-expression in SUS } \\
\text { TMPRSS } 2 \text { expressed in all support cells, } \\
\text { BG, BC expression not determined } \\
\text { ACE } 2 \text { express in RE of nasal cavity, but with lower } \\
\text { intensity }\end{array}$ \\
\hline Dtsch Arztebl Int & 2020 & Brelie $^{(46)}$ & SARS-CoV-2 & Case report, MRI & Olfactory cleft opacification $0 / 1$ \\
\hline preprint & 2020 & Bryche $^{(43)}$ & SARS-CoV-2 & Animal model & $\begin{array}{l}\text { Sustentacular cells rapidly infected at day } 4, \text { OSN } \\
\text { significantly reduced, }\end{array}$ \\
\hline preprint & 2020 & Butler $^{(73)}$ & SARS-CoV-2 & RNAseq & $\begin{array}{l}\text { Odourant receptors pathways down regulated as } \\
\text { a result of infection }\end{array}$ \\
\hline Science & 2020 & $\begin{array}{l}\text { Cantuti- } \\
\text { Castelvetri(68) }\end{array}$ & SARS-CoV-2 & $\begin{array}{l}\text { Immunohistoche- } \\
\text { mistry }\end{array}$ & $\begin{array}{l}\text { Neuropilin- } 1 \text { is highly expressed in olfactory } \\
\text { epithelial cells and can enhance infection of the } \\
\text { olfactory epithelium }\end{array}$ \\
\hline preprint & 2020 & Cardenas $^{(70)}$ & SARS-CoV-2 & Biopsy & $\begin{array}{l}\text { Nasal ACE2 hypomethylation in women and } \\
\text { Black invididuals }\end{array}$ \\
\hline ACS Chem Neurosci & 2020 & Cazzolla $a^{(66)}$ & SARS-CoV-2 & Case cohort & II-6 is elevated in patients with anosmia \\
\hline J Infect & 2020 & Chetrit $^{(47)}$ & SARS-CoV-2 & Case cohort, MRI & Olfactory cleft opacification 9/19 \\
\hline Neurology & 2020 & Eliezer $^{(55)}$ & SARS-CoV-2 & Case cohort, MRI & Olfactory cleft opacification 19/20 \\
\hline iScience & 2020 & Fodoulian ${ }^{(37)}$ & SARS-CoV-2 & RNAseq & $\begin{array}{l}\text { ACE2 and TMPRSS2 in support cells, } \\
\text { No ACE2 in OSN }\end{array}$ \\
\hline Acad Radiol & 2020 & Galougahi $^{(56)}$ & SARS-CoV-2 & Case report, MRI & Olfactory cleft opacification $0 / 1$ \\
\hline Acta Cytol & 2020 & Gelardi $^{(58)}$ & SARS-CoV-2 & Cytology & No cytological signs of extensive cell injury \\
\hline Am J Otolaryngol & 2020 & Gelardi $^{(59)}$ & SARS-CoV-2 & Cytology & No cytological signs of extensive cell injury \\
\hline preprint & 2020 & Girardeau $^{(49)}$ & SARS-CoV-2 & Case cohort, MRI & Olfactory cleft opacification 2/10 \\
\hline Brief Bioinform & 2020 & Gupta ${ }^{(38)}$ & SARS-CoV-2 & RNA & $\begin{array}{l}\text { ACE2 and TMPRSS2 in support cells, } \\
\text { No ACE2 and TMPRSS } 2 \text { in OSN }\end{array}$ \\
\hline Lancet & 2020 & Kirschenbaum $^{(60)}$ & SARS-CoV-2 & $\begin{array}{l}\text { Immunohistoche- } \\
\text { mistry }\end{array}$ & $\begin{array}{l}\text { Mucosal atrophy and neuritis in biopsy of olfac- } \\
\text { tory tissue }\end{array}$ \\
\hline Neurology & 2020 & Laurendon $^{(50)}$ & SARS-CoV-2 & Case report, MRI & Olfactory cleft opacification 1/1 \\
\hline Laryngoscope & 2020 & Lechien $^{(51)}$ & SARS-CoV-2 & Case cohort, CT & Olfactory cleft opacification 3/16 \\
\hline preprint & 2020 & Melo $^{(64)}$ & SARS-CoV-2 & RNAseq & $\begin{array}{l}\text { Increase of pro inflammatory cytokines may } \\
\text { damage the olfactory epithelium }\end{array}$ \\
\hline $\begin{array}{l}\text { JAMA Otolaryngol } \\
\text { Head Neck Surg }\end{array}$ & 2020 & Morbini $^{(61)}$ & SARS-CoV-2 & $\begin{array}{l}\text { Immunohistoche- } \\
\text { mistry }\end{array}$ & Macrophage activation in olfactory epithelium \\
\hline preprint & 2020 & . & SARS-CoV-2 & RNAseq & $\begin{array}{l}\text { ACE2 and TMPRSS2 in all support cells } \\
\text { ACE2 and CTSL in olfactory epithelium }\end{array}$ \\
\hline Int J Infect Dis & 2020 & Nakagawara ${ }^{(63)}$ & SARS-CoV-2 & Case cohort & $\begin{array}{l}\text { Patients with anosmia have higher viral loads } \\
\text { and longer time to viral clearance }\end{array}$ \\
\hline preprint & 2020 & $\mathrm{Papa}^{(69)}$ & SARS-CoV-2 & $\begin{array}{l}\text { Immunohistochemis- } \\
\text { try, CRISPR }\end{array}$ & $\begin{array}{l}\text { Furin enhances infection and cell to transmission } \\
\text { but not essential for infection }\end{array}$ \\
\hline preprint & 2020 & Rodriguez $^{(67)}$ & SARS-CoV-2 & Immunhistochemistry & $\begin{array}{l}\text { IFN1 secretion from sustentacular cells stimu- } \\
\text { lates ACE2 expression in olfactory epithelium } \\
\text { IFN1 and other cytokines activate OSN immune } \\
\text { cascades, resulting in downregulation of olfac- } \\
\text { tory receptors }\end{array}$ \\
\hline preprint & 2020 & Santos ${ }^{(71)}$ & SARS-CoV-2 & Observational cohort & $\begin{array}{l}\text { Less TMPRSS2 in European than in Asian indivi- } \\
\text { duals }\end{array}$ \\
\hline Nature & 2020 & $\operatorname{Sia}^{(44)}$ & SARS-CoV-2 & Animal model & $\begin{array}{l}\text { moderate inflammatory cell infiltrate in nasal tur- } \\
\text { binate, viral antigen detectable in nasal mucosa } \\
\text { and ORN } \\
\text { reduced number of OSN at day } 2 \text {, nasal epithelial } \\
\text { attenuation on day } 7 \text {, tissue repair at day } 14\end{array}$ \\
\hline $\begin{array}{l}\text { Eur Arch Otorhinola- } \\
\text { ryngol }\end{array}$ & 2020 & Spoldi ${ }^{(53)}$ & SARS-CoV-2 & Case cohort, CT & Olfactory cleft opacification $16 / 63$ \\
\hline ACS Chem Neurosci & 2020 & Torabi $^{(65)}$ & SARS-CoV-2 & Case cohort, biopsy & $\begin{array}{l}\text { increased TNFa, c } \\
\text { an lead to olfactory submucosa expansion and } \\
\text { inhibit basal cells }\end{array}$ \\
\hline
\end{tabular}




\begin{tabular}{|c|c|c|c|c|c|}
\hline Journal & Year & First author & Virus & Design & Outcomes \\
\hline Eur J Neurol & 2020 & Tsivgoulis ${ }^{(54)}$ & SARS-CoV-2 & Case cohort, MRI & Olfactory cleft opacification $3 / 8$ \\
\hline preprint & 2020 & Ueha ${ }^{(40)}$ & SARS-CoV-2 & Immunhistochemistry & $\begin{array}{l}\text { ACE and TMPRSS } 2 \text { co-expression in all tissue, } \\
\text { including OSN } \\
\text { Furin in SUS and BG's }\end{array}$ \\
\hline Clin Infect Dis & 2020 & Zhang $^{(45)}$ & SARS-CoV-2 & Animal model & $\begin{array}{l}\text { Rapid disorganisation of olfactory epithelium } \\
\text { after challenge, including OSNs }\end{array}$ \\
\hline Cell & 2020 & Ziegler $^{(41)}$ & SARS-CoV-2 & RNAseq & $\begin{array}{l}\text { ACE2 and TMPRSS2 in support cells, } \\
\text { No ACE2 in OSN }\end{array}$ \\
\hline preprint & 2020 & Meinhardtt ${ }^{(62)}$ & SARS-CoV-2 & Case cohort, biopsy & $\begin{array}{l}\text { Virus present in olfactory mucosa and } \\
\text { axon damage }\end{array}$ \\
\hline Sci Adv & 2020 & Brann $^{(36)}$ & SARS-CoV-2 & RNAseq & $\begin{array}{l}\text { ACE2 } 2 \text { and TMPRSS } 2 \text { in support cells } \\
\text { No ACE2 and TMPRSS } 2 \text { in OSN } \\
\text { ACE2 and TMPRSS } 2 \text { upregulation after tissue } \\
\text { damage }\end{array}$ \\
\hline Eur Respir J & 2020 & Chen ${ }^{(42)}$ & SARS-CoV-2 & $\begin{array}{l}\text { Immunohistoche- } \\
\text { mistry }\end{array}$ & $\begin{array}{l}\text { ACE2 and TMPRSS } 2 \text { in SUS and BG } \\
\text { No ACE2 and TMPRSS } 2 \text { in OSN }\end{array}$ \\
\hline Rhinology Online & 2020 & Root-Bernstein ${ }^{(72)}$ & SARS-CoV-2 & $\begin{array}{l}\text { Proteonomic simila- } \\
\text { rity searching (BLAST) }\end{array}$ & $\begin{array}{l}\text { SARS-CoV-2 mimics human odourant receptors, } \\
\text { which could block by OSNs by lgA made against } \\
\text { the virus }\end{array}$ \\
\hline
\end{tabular}

